\title{
STRATEGI ALOKASI ANGGARAN UNTUK PENURUNAN DISPARITAS PEMBANGUNAN EKONOMI ANTAR KECAMATAN DI KABUPATEN CIREBON
}

\author{
Budget Allocation Strategy to Decrease Disparity in Economic Development Between \\ Sub-districts in Cirebon District
}

\section{Januri', Ma'mun Sarma², A Faroby Falatehan ${ }^{3}$}

\author{
${ }^{1}$ Kepala Sub Bagian Umum dan Keuangan. Kecamatan Losari Kabupaten Cirebon. Email: \\ janurivijay@yahoo.com \\ 2Staff Pengajar Departemen Manajemen, Fakultas Manajemen dan Ekonomi. IPB. Email: \\ mamun_sarma@yahoo.com
}

3Staff Pengajar Departemen Ekonomi Sumberdaya dan Lingkungan. Fakultas Ekonomi dan Manajemen. IPB. Email : robie_fa@yahoo.com

\begin{abstract}
Cirebon District consists of 40 sub-districts with various potentials and characteristics between subdistricts, this condition causes disparity in the development between sub-districts in Cirebon District. This study was aimed to analyze the pattern of economic growth and development of each sub-district, measure the level of disparity, analyze the factors causing disparity, and establish the priority of budget allocation strategy to decrease disparity in economic development between sub-districts in Cirebon District. Primary data were obtained from gathering opinion with questionnaire by respondents who are steakholder were chosen purposively. The methods of analysis used in each aim were: analysis Tipology Klassen, Entropy Index, Williamson Index, Theil Index, panel data regression, and Analytical Hierarchy Process (AHP). The results of each analysis showed that: (1) Sub-district in Cirebon District was classified into four quadrants, the level of development of undeveloped sub districts optimally and uneven; (2) the level of disparity in in Cirebon District fluctuated, and the decomposition of the major source of disparity was caused by the disparity between sub-districts (within region); (3) factors which had a significant influence to the decrease of disparity, namely income per capita (regional GDP) and the development of sub-district; and (4) priority of budget allocation strategy that can be implemented to decrease the disparity between sub-districts in Cirebon District is the improvement of infrastructure and facilities.
\end{abstract}

Keywords: Disparity Development, Cirebon District, Theil Index, Analytical Hierarchy Process

\begin{abstract}
ABSTRAK
Kabupaten Cirebon terdiri dari 40 kecamatan dengan potensi dan karakteristik antar kecamatan yang beragam, yang mengakibatkan terjadinya disparitas pembangunan antar kecamatan di Kabupaten Cirebon. Penelitian ini bertujuan untuk: menganalisis pola pertumbuhan ekonomi dan perkembangan kecamatan, mengukur tingkat disparitas, menganalisis faktor-faktor penyebab disparitas, dan menetapkan prioritas strategi alokasi anggaran untuk penurunan disparitas pembangunan ekonomi antar kecamatan di Kabupaten Cirebon. Data primer diperoleh dengan penjaringan pendapat stakeholder yang masing-masing dipilih secara sengaja (puposive sampling). Metode analisis yang digunakan untuk masing-masing tujuan adalah: analisis Tipology Klassen, Indeks Entropi, Indeks Williamson, Indeks Theil, regresi data panel, dan Proses Hirarki Analitik (PHA). Hasil dari masing-masing analisis menunjukkan bahwa: (1) Kecamatan di Kabupaten Cirebon diklasifikasikan menjadi 4 kuadran dan tingkat perkembangan kecamatan belum berkembang secara optimal dan belum merata; (2) disparitas di Kabupaten Cirebon bersifat fluktuatif, dan dekomposisi sumber utama disparitas berasal dari disparitas antar kecamatan dalam wilayah (within region); (3) faktor yang berpengaruh terhadap disparitas adalah pendapatan (PDRB) per kapita dan perkembangan kecamatan; dan (4) prioritas strategi alokasi anggaran yang dapat diimplementasikan untuk penurunan disparitas pembangunan ekonomi di Kabupaten Cirebon adalah peningkatan prasarana dan sarana.
\end{abstract}

Kata kunci: disparitas pembangunan, Kabupaten Cirebon, Indeks Theil, Proses Hirarki Analitik 


\section{PENDAHULUAN}

Disparitas pembangunan ekonomi tidak hanya terjadi antar wilayah/provinsi di Indonesia, namun juga terjadi antar kabupaten/kota dalam provinsi dan antar kecamatan dalam kabupaten/kota. Berdasarkan data BPS, tingkat disparitas atau ketimpangan yang terjadi di Provinsi Jawa Barat selama periode 2000-2014 cenderung tinggi dan nilainya lebih dari 0.5 yaitu 0.696 sampai dengan 0.678 yang termasuk kategori disparitas tinggi (BPS Provinsi Jawa Barat, 2015).

Adanya disparitas pembangunan yang terjadi antar kabupaten/kota di Provinsi Jawa Barat, diduga terjadi juga di wilayah kabupaten/kota itu sendiri, seperti halnya kemungkinan terjadinya disparitas antar kecamatan di Kabupaten Cirebon, yang diproksi oleh adanya pertumbuhan ekonomi dan pendapatan (PDRB) per kapita antar kecamatan yang timpang. Dugaan terjadinya disparitas atau ketimpangan di Kabupaten Cirebon ini mengakibatkan adanya wacana pemekaran wilayah antara Cirebon Bagian Barat dan Cirebon Bagian Timur, dan disparitas pembangunan yang terjadi telah mendorong masyarakat di wilayah Cirebon Timur untuk membentuk daerah otonomi tersendiri.

Kondisi pertumbuhan ekonomi antar kecamatan di Kabupaten Cirebon saat ini tidak merata, begitu pun tingkat pendapatan (PDRB) per kapita antar kecamatan di Kabupaten Cirebon tidak merata. Ada beberapa kecamatan yang memiliki pertumbuhan ekonomi dan pendapatan (PDRB) per kapita sangat tinggi dan ada juga kecamatan yang memiliki pertumbuhan ekonomi dan pendapatan (PDRB) per kapita sangat rendah. Kecamatan Plered merupakan kecamatan dengan pertumbuhan ekonomi tertinggi pada tahun 2015 yaitu sebesar 7,79 persen, sedangkan Kecamatan Greged merupakan kecamatan dengan pertumbuhan ekonomi terendah yaitu sebesar 0,97 persen. Tingkat pendapatan (PDRB) per kapita yang tertinggi adalah Kecamatan Depok sebesar 38,28 juta rupiah, sedangkan Kecamatan Beber merupakan kecamatan dengan PDRB per kapita terendah yaitu 7,81 juta rupiah (BAPPEDA Kabupaten Cirebon, 2016).

Adanya perbedaan kondisi ini diduga akan menyebabkan disparitas pembangunan ekonomi antar kecamatan di Kabupaten Cirebon, karena dengan kondisi ini akan berdampak terhadap tingkat perkembangan kecamatan yang berbeda, ada kecamatan yang mengalami perkembangan dan pembangunan cepat, sedang atau stagnan, bahkan ada juga kecamatan yang mengalami perkembangan dan pembangunan lambat atau relatif tertinggal. Terjadinya disparitas pembangunan ekonomi antar wilayah ini membawa implikasi terhadap tingkat kesejahteraan masyarakat antar kecamatan. Karena itu, aspek disparitas pembangunan ekonomi antar wilayah ini juga mempunyai implikasi pula terhadap formulasi kebijakan pembangunan ekonomi wilayah yang dilakukan oleh pemerintah daerah (Syafrizal, 2014).

Pembangunan ekonomi akan menciptakan pertumbuhan ekonomi dan kemakmuran masyarakat yang adil dan merata apabila pertumbuhan tersebut dihasilkan oleh banyak orang. Untuk itu pembangunan mengharuskan adanya tingkat GNI yang tinggi dan pertumbuhan berkelanjutan, apabila peningkatan pertumbuhan ekonomi hanya dilakukan oleh segelintir orang kaya maka peningkatan hasil kemungkinan besar menguntungkan mereka, kemajuan upaya menangulangi kemiskinan akan bergerak lamban dan disparitas akan memburuk. Namun jika pertumbuhan yang dihasilkan oleh orang banyak, maka mereka pulalah yang akan memperoleh manfaat besarnya dan hasil pertumbuhan ekonomi akan terbagi lebih merata. Oleh karena itu, tingkat pertumbuhan yang tinggi tidak mencerminkan adanya ungkapan si kaya 
bertambah kaya dan si miskin bertambah miskin (Todaro dan Smith, 2011). Berkaitan dengan pemerataan pembangunan, maka pemerintah perlu melakukan strategi alokasi anggaran untuk penurunan disparitas pembangunan ekonomi antar kecamatan di Kabupaten Cirebon.

Tujuan dari penelitian ini adalah: (1) Menganalisis pola pertumbuhan ekonomi dan perkembangan wilayah tiap kecamatan di Kabupaten Cirebon; (2) Mengukur tingkat disparitas pembangunan ekonomi antar kecamatan di kabupaten Cirebon; (3) Menganalisis faktor-faktor penyebab disparitas pembangunan ekonomi antar kecamatan di Kabupaten Cirebon; dan (4) Menetapkan prioritas strategi alokasi anggaran untuk penurunan disparitas pembangunan ekonomi antar kecamatan di Kabupaten Cirebon

\section{METODOLOGI}

Penelitian dilakukan di Kabupaten Cirebon yang terdiri dari 40 kecamatan. Data primer pada penelitian diperoleh melalui penjaringan pendapat steakholder yang terdiri dari unsur Pemerintah Kabupaten Cirebon, Dewan Perwakilan Rakyat Daerah (DPRD) Kabupaten Cirebon, pengusaha/pelaku usaha, LSM, dan tokoh masyarakat di Kabupaten Cirebon. Responden ditentukan secara sengaja (purpose sampling). Data sekunder merupakan data atau dokumen yang diperoleh dari instansi/lembagalembaga terkait yang relevan dalam penelitian ini. Tahapan yang dilakukan dalam analisis data sesuai dengan urutan tujuan adalah: (1) analisis Tipologi Klassen dan Entropi, (2) analisis Indeks Williamson dan Indeks Theil, (3) analisis regresi data panel, dan (4) Proses Hirarki Analitik (PHA).

Analisis Tipologi Klassen dilakukan untuk menentukan klasifikasi pola pertumbuhan ekonomi masing- masing kecamatan dengan membandingkan laju pertumbuhan ekonomi dan pendapatan (PDRB) per kapita tiap kecamatan terhadap pertumbuhan ekonomi dan pendapatan (PDRB) per kapita rata-rata kabupaten. Sedangkan analisis Entropi dilakukan untuk mengukur tingkat perkembangan kecamatan dan melihat sektor-sektor perekonomian yang dominan dan berkembang pada kecamatan tersebut.

Analisis Indeks Williamson dilakukan untuk mengukur tingkat disparitas pembangunan ekonomi di Kabupaten Cirebon. Untuk menguraikan disparitas antar kecamatan (betweenregion inequality) dan disparitas antar kecamatan dalam wilayah (within-region inequality) digunakan analisis Indeks Theil. Selain itu, Indeks Theil juga digunakan untuk mengukur kontribusi masing-masing kecamatan terhadap disparitas pembangunan di Kabupaten Cirebon secara keseluruhan sehingga dapat memberikan kebijakan yang cukup penting.

Analisis regresi linier berganda (data panel) digunakan untuk mengetahui besarnya pengaruh dari suatu variabel bebas (independent variable) yang terdiri dari laju pertumbuhan ekonomi, pendapatan (PDRB) per kapita, dan perkembangan kecamatan, terhadap variabel terikat (dependent variable) yaitu tingkat disparitas pembangunan ekonomi. Adapun metode yang digunakan dalam penelitian adalah metode OLS (Ordinary Least Square).

Proses Hirarki Analisis (PHA) dilakukan untuk menentukan prioritas strategi alokasi anggaran untuk menurunkan disparitas pembangunan ekonomi antar kecamatan di Kabupaten Cirebon. Analisis ini dilakukan untuk menangkap secara rasional persepsi steakholder melalui prosedur yang didesain untuk sampai pada skala preferensi diantara berbagai set alternatif. Penerapan AHP pada analisis 
manfaat/biaya digunakan skala perbandingan berpasang untuk mengkuantifikasi faktor non ekonomi, yang sejauh ini belum terintegrasi secara efektif dalam pengambilan keputusan, dan dimungkinkan dalam melakukan perbandingan yang eksplisit, terinformasi diantara banyak kriteria, guna pemilihan kebijakan atau proyek (Falatehan, 2016).

\section{HASIL DAN PEMBAHASAN}

\section{Pola Pertumbuhan Ekonomi dan Perkembangan Kecamatan}

Pola pertumbuhan ekonomi kecamatan di Kabupaten Cirebon dapat diklasifikasikan menjadi empat kuadran yaitu: (1) Kuadran I adalah kecamatan yang maju dan tumbuh cepat yaitu kecamatan yang laju pertumbuhan ekonomi dan PDRB per kapita lebih tinggi dari rata-rata Kabupaten Cirebon; (2) Kuadran II adalah kecamatan maju tapi tertekan yaitu kecamatan yang laju pertumbuhan ekonomi lebih rendah dari rata-rata kecamatan di wilayah Kabupaten Cirebon, sedangkan PDRB per kapitanya lebih tinggi dari rata-rata kecamatan di wilayah Kabupaten Cirebon; (3) Kuadran III adalah kecamatan yang berkembang cepat, yaitu kecamatan yang laju pertumbuhan ekonomi lebih tinggi dari rata-rata kecamatan di wilayah Kabupaten Cirebon, tetapi PDRB per kapita lebih rendah dari rata-rata keamatan di wilayah Kabupaten Cirebon; dan Kuadran IV adalah kecamatan yang relatif tertinggal, yaitu kecamatan yang laju pertumbuhan ekonomi dan PDRB per kapita lebih rendah dari rata-rata kecamatan di Kabupaten Cirebon, seperti pada Tabel 1.

Tabel 1 Klasifikasi pola pertumbuhan ekonomi Kabupaten Cirebon tahun 2015 menurut Tipologi Klassen

\begin{tabular}{lll}
\hline \multicolumn{1}{c}{ Laju Pertumbuhan } \\
$\begin{array}{l}\text { Pendapatan } \\
\text { Per Kapita }\end{array}$ & $\begin{array}{c}\text { Laju Pertumbuhan di Atas Rata- } \\
\text { rata }\end{array}$ & $\begin{array}{l}\text { Laju Pertumbuhan di Bawah } \\
\text { Rata-rata }\end{array}$ \\
\hline $\begin{array}{l}\text { Pendapatan Per Kapita di Atas } \\
\text { Rata-rata }\end{array}$ & $\begin{array}{l}\text { Kecamatan Maju: } \\
\text { Palimanan, Plumbon, Depok, } \\
\text { Plered, Kedawung, Jamblang, } \\
\text { Arjawinangun, Gempol, Pabuaran, } \\
\text { Karangwareng, dan Astanajapura }\end{array}$ & $\begin{array}{l}\text { Kecamatan Maju Tapi } \\
\text { Tertekan: } \\
\text { Ciledug, Susukan Lebak, Weru, } \\
\text { dan Panguragan }\end{array}$ \\
\hline \multirow{3}{*}{$\begin{array}{ll}\text { Kendapatan Per Kapita di } \\
\text { Bawah Rata-rata }\end{array}$} & $\begin{array}{l}\text { Kabakan, Lemahabang, Pangenan, } \\
\text { Talun, Dukupuntang, Tengahtani, }\end{array}$ & $\begin{array}{l}\text { Waled, Pasaleman, Losari, } \\
\text { Pabedilan, Gebang, }\end{array}$ \\
& Kapetakan, dan Klangenan & $\begin{array}{l}\text { Karangsembung, Sedong, Mundu, } \\
\text { Beber, Greged, Sumber, Gunung }\end{array}$ \\
& & $\begin{array}{l}\text { Jati, Suranenggala, Ciwaringin, } \\
\text { Susukan, Gegesik, dan Kaliwedi }\end{array}$ \\
\hline
\end{tabular}

Sumber: BAPPEDA Kabupaten Cirebon, 2016 (data diolah)

Kecamatan relatif tertinggal memiliki persentase sebesar 42.50 persen, sedangkan kecamatan maju dan tumbuh cepat memiliki persentase sebesar 27.50 persen. Kecamatan yang termasuk dalam kategori kecamatan berkembang sebanyak 8 kecamatan atau 20.00 persen. atau 10.00 persen. Dari perbandingan persentasi pada masing-masing kategori kecamatan, terlihat bahwa jumlah kecamatan relatif tertinggal di Kabupaten Cirebon masih sangat banyak, dan jumlahnya hampir setengahnya dari seluruh kecamatan yang ada di Kabupaten Cirebon. maju tapi tertekan sebanyak 4 kecamatan 
Banyaknya kecamatan yang relatif tertinggal terjadi karena adanya potensi dan karakteristik di tiap kecamatan yang berbeda, baik sumber daya alam maupun sumber daya manusia. Selain itu juga karena belum tersedianya prasarana dan sarana yang memadai di tiap kecamatan secara merata, terutama akses jalan untuk menghubungkan berbagai konsentrasi kegiatan ekonomi, hal ini karena proses pembangunan akan lebih cepat pada kecamatan dengan konsentrasi kegiatan ekonomi yang lebih tinggi, sedangkan kecamatan dengan konsentrasi kegiatan ekonomi rendah proses pembangunan akan berjalan lebih lambat. Oleh karena itu, ketidakmerataan ini menimbulkan disparitas pembangunan antar kecamatan yang diproksi dengan banyaknya kecamatan yang relatif tertinggal. Dengan demikian Pemerintah Daerah harus pandai memilah skala prioritas pembangunan sebagaimana diungkapkan Amrillah dan Yasa (2013), bahwa mengingat adanya keterbatasan dana pembangunan, maka pemerintah seharusnya memprioritaskan anggaran untuk mengembangkan sektor-sektor ekonomi yang potensial di tiap-tiap kecamatan tanpa mengabaikan sektor yang tidak potensial.

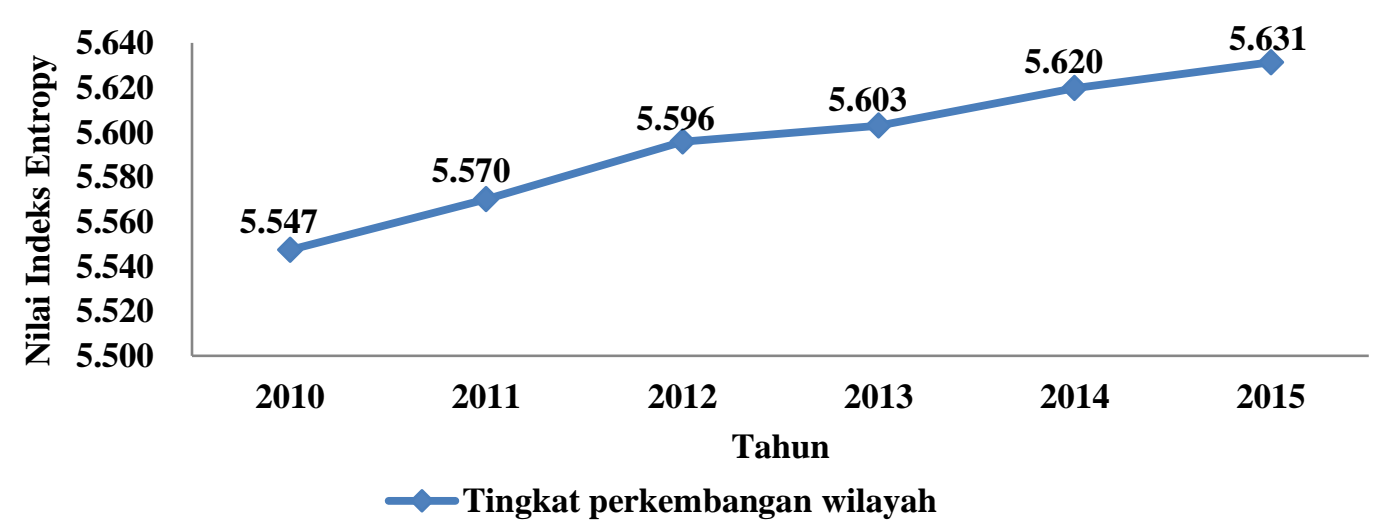

Sumber: BAPPEDA Kabupaten Cirebon, 2016

Gambar 1 Tingkat perkembangan wilayah Kabupaten Cirebon tahun 2010-2015

Berdasarkan Gambar 1, menunjukkan bahwa tingkat perkembangan kecamatan di Kabupaten Cirebon sampai saat ini masih belum berkembang secara optimal dan belum merata. Selama periode tahun 2010 hingga tahun 2015 pada tingkat kecamatan rata-rata memiliki nilai yang relatif tetap, sedangkan pada tingkat kabupaten nilai Indeks Entropi cenderung meningkat. Nilai Indeks Entropi Kabupaten Cirebon pada tahun 2010 sebesar 0,851 dan meningkat menjadi 0,863 pada tahun 2015. Begitu pun nilai entropi total pada tingkat kecamatan ratarata relatif tetap, sedangkan pada tingkat kabupaten terjadi peningkatan nilai entropi total yaitu pada tahun 2010 sebesar 5,547 meningkat menjadi 5,631 pada tahun 2015. Kondisi ini mengindikasikan bahwa selama kurun waktu tersebut proporsi keragaman sektor-sektor perekonomian tiap kecamatan relatif stabil sehingga komposisi sektor-sektor perekonomian di Kabupaten Cirebon cenderung kurang berkembang.

Nilai Entropi maksimum yang mampu dihasilkan Kabupaten Cirebon pada tahun 2015 adalah 5,631 dan perkembangan wilayah yang mampu dicapai sekitar 86,34 persen. Nilai entropi total tiap kecamatan dapat dilihat pada Gambar 2. 


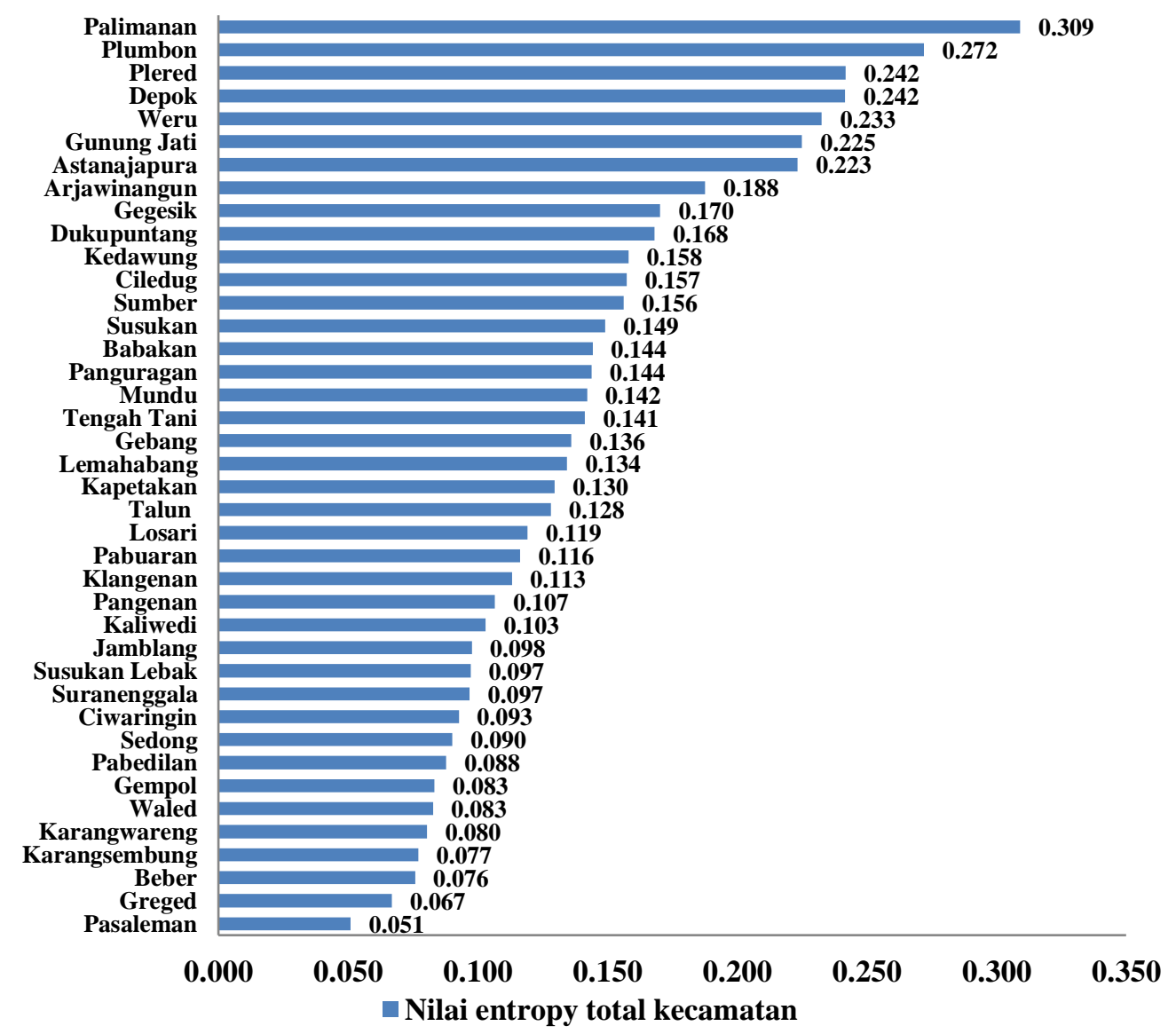

Sumber: BAPPEDA Kabupaten Cirebon, 2016

Gambar 2 Nilai entropi total tiap kecamatan di Kabupaten Cirebon tahun 2015

Berdasarkan Gambar 2, terlihat bahwa keberagaman aktivitas Kecamatan Palimanan sebesar 5,49 persen jauh lebih tinggi dibandingkan dengan kecamatan lainnya yang rata - rata diversifikasi ekonominya hanya sebesar 2,42 persen. Nilai entropi Kecamatan Palimanan sebesar 0,309 jauh di atas rata-rata nilai entropi kecamatan yaitu sebesar 0,140 dari 5,631 total entropi kecamatan yang ada jelas sangat mempengaruhi perkembangan Kabupaten Cirebon secara keseluruhan. Nilai entropi Kecamatan Palimanan yang jauh lebih tinggi dibandingkan dengan kecamatan lainnya, menunjukan bahwa sektor perekonomian di Kabupaten Cirebon tidak terdistribusi secara merata. Secara lengkap Indeks Entropi sektoral dapat dilihat pada Tabel 2.
Indeks Entropi tertinggi secara sektoral di Kabupaten Cirebon dimiliki oleh sektor industri pengolahan dengan 0,87 atau sekitar 15,41 persen dari total tujuh belas sektor yang dianalisis. Ini menunjukkan bahwa sektor industri pengolahan menjadi sektor utama yang dimiliki oleh sebagian besar kecamatan yang ada di Kabupaten Cirebon. Sektor berikutnya adalah sektor perdagangan besar dan eceran, reparasi mobil dan sepeda motor dengan indeks 0,85 atau sekitar 15,16 persen, sektor pertanian kehutanan dan perikanan dengan indeks 0,80 atau sekitar 1,24 persen, dan sektor konstruksi dengan indeks 0,69 atau sekitar 12,21 persen. Sedangkan sektor keragaman paling rendah adalah sektor pengadaan listrik dan gas dengan indeks 0,01 atau sekitar 0,25 persen. 
Tabel 2 Indeks Entropi Antar Kecamatan Di Kabupaten Cirebon Tahun 2015

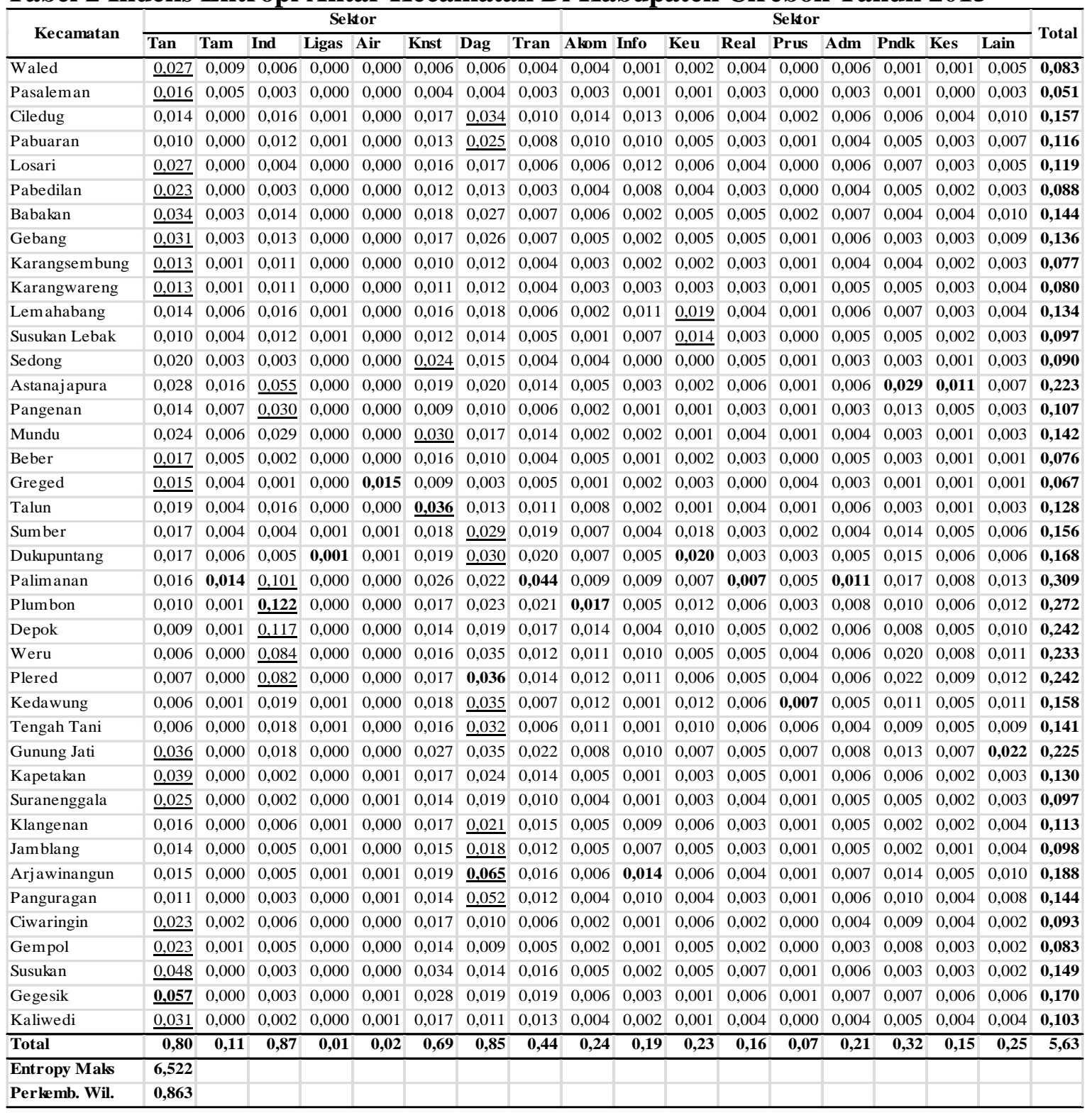

Sumber: BAPPEDA Kabupaten Cirebon, 2016 (data diolah)

Keterangan: $\quad$ Tan $=$ pertanian, kehutanan, dan perikanan, Tam $=$ pertambangan dan penggalian, Ind $=$ industri pengolahan, Ligas = pengadaan listrik dan gas, Air = pengadaan air, pengelolaan sampah, dan daur ulang, Knst $=$ konstruksi, Dag $=$ perdagangan besar dan eceran, reparasi mobil dan sepeda motor, Tran $=$ transportasi dan pergudangan, Akom = penyediaan akomodasi \& makan minum, Info $=$ informasi dan komunikasi, $\mathrm{Keu}=$ jasa keuangan dan asuransi, Real $=$ real estate, Prus $=$ jasa perusahaan, Adm $=$ administrasi pemerintahan, pertahanan $\&$ jaminan sosial wajib, Pndk $=$ jasa pendidikan, Kes $=$ jasa kesehatan $\&$ kegiatan sosial, Lain = jasa lainnya

Keragaman yang rendah pada tiap kecamatan sebagian besar terjadi karena hanya mengandalkan sektor pertanian dan perikanan. Sektor tersebut sebenarnya merupakan sektor yang memiliki potensi sumberdaya alam yang sangat besar di Kabupaten Cirebon, namun cenderung memiliki keterkaitan hubungan yang relatif kecil dengan sektor produksi atau sektor ekonomi lainnya, walaupun memberikan kontribusi yang dominan. Oleh karena itu, Pemerintah 
Daerah perlu memperhatikan sektor ekonomi yang mempunyai potensi daya saing kompetitif maupun komparatif yang lebih unggul dibandingkan dengan pertumbuhan total kegiatan ekonomi, artinya mempunyai prospek untuk dipasarkan ke luar wilayah atau di ekspor di masa yang akan datang dan dapat dikembangkan secara besar-besaran atau volume produksinya memenuhi syarat untuk di ekspor untuk masing-masing daerah penelitian perlu didorong, dikembangkan dan disinergikan dengan sektor-sektor lain yang terkait agar terdapat dampak pengganda yang cukup berarti yang akan mempercepat pertumbuhan ekonomi wilayah (Titisari, 2010).

\section{Tingkat Disparitas Pembangunan Ekonomi Antar Kecamatan}

Tingkat disparitas di Kabupaten Cirebon selama kurun waktu 2010-2015 berfluktuatif dan cenderung akan meningkat, seperti pada Gambar 3. Nilai Indeks Williamson dari tahun 2010 sampai tahun 2015 menunjukkan bahwa telah terjadi disparitas pembangunan di wilayah Kabupaten Cirebon dengan tingkat sedang (Iw : 0,3 - 0,5), dimana disparitas tertinggi terjadi pada tahun 2011 dengan nilai Indeks Williamson sebesar 0,433.

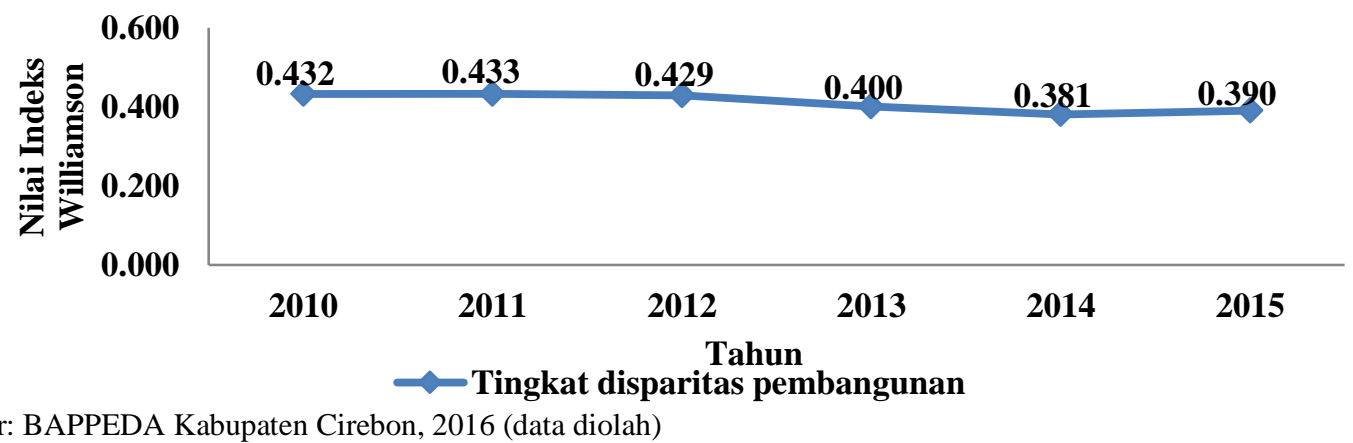

Sumber: BAPPEDA Kabupaten Cirebon, 2016 (data diolah)

\section{Gambar 3 Indeks disparitas Kabupaten Cirebon tahun 2010-2015}

Besarnya disparitas (disparitas total) yang didekomposisi menjadi disparitas antar wilayah bagian timur (WBT) dengan wilayah bagian barat
(WBB) Kabupaten Cirebon (between region) dan disparitas dalam wilayah (within region), juga menunjukkan hasil yang fluktuatif seperti pada Gambar 4.

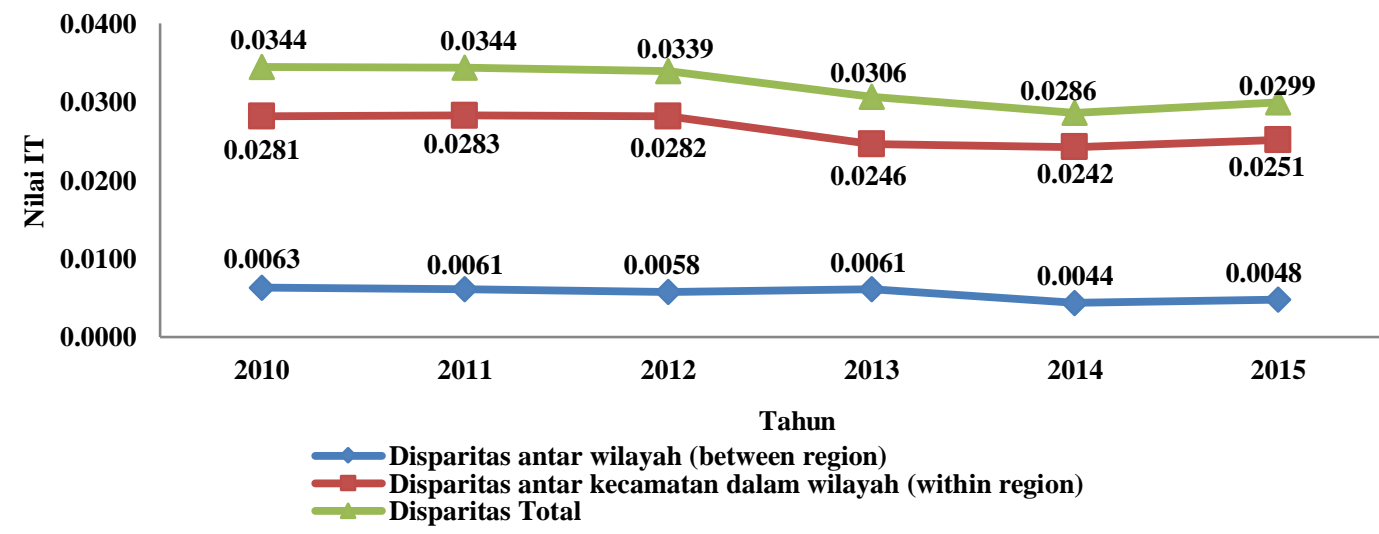

Sumber: BAPPEDA Kabupaten Cirebon, 2016 (data diolah)

Gambar 4 Dekomposisi disparitas wilayah di Kabupaten Cirebon tahun 2010-2015 
Berdasarkan Gambar 5, menunjukkan bahwa selama tahun 2010 2015 sumber utama disparitas di Kabupaten Cirebon disebabkan oleh disparitas antar kecamatan dalam wilayah (within region) yang mencapai 81,68 persen pada tahun 2010 dan menjadi
83,98 persen pada tahun 2015 . Sementara dekomposisi sumber disparitas antar WBB dan WBT di Kabupaten Cirebon hanya sebesar 18,32 persen pada tahun 2010 dan menurun 16,02 persen pada tahun 2015.

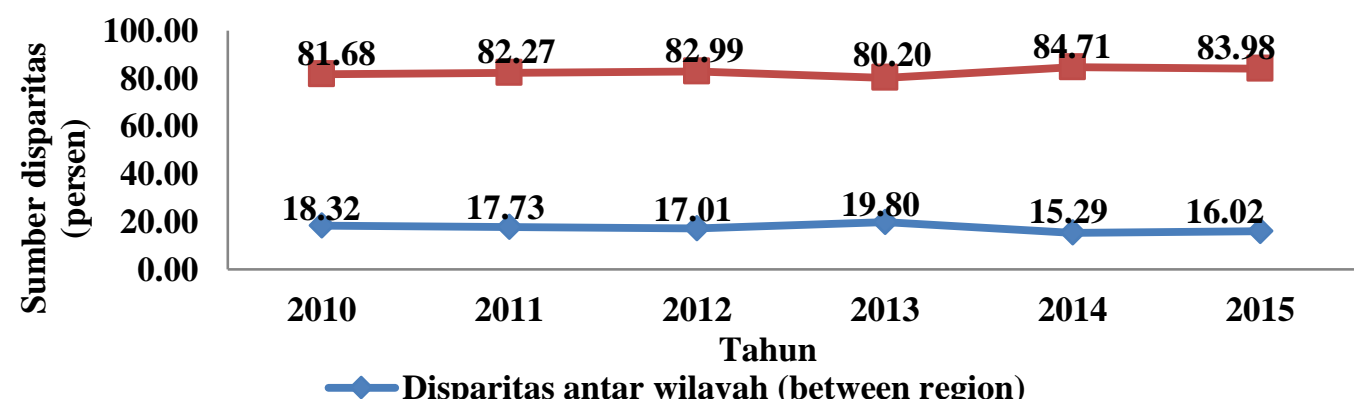

Sumber: BAPPEDA Kabupaten Cirebon, 2016 (data diolah)

Gambar 5 Persentase sumber disparitas di Kabupaten Cirebon tahun 2010-2015

Implikasi dari tingginya disparitas antar kecamatan dalam wialayah (within region) dibandingkan disparitas pembangunan antar wilayah (between region) secara keseluruhan adalah pemerintah Kabupaten Cirebon dalam mengambil kebijakan pengembangan wilayah tidak bisa dipandang dalam lingkup wilayah pembangunan, namun harus lebih spesifik lagi yaitu dalam lingkup kecamatan, sehingga kebijakan yang diambil disesuaikan dengan karakteristik dan potensi masing-masing kecamatan. Salah satu konsep yang dapat dikembangkan adalah pembangunan endogen, yaitu strategi pembangunan yang ditentukan sendiri (self-determined) yang bersifat partisipatif yang berbasiskan pada kebutuhan lokal dan penggunaan potensi-potensi endogen (Muhlighaus \& Walty, 2001).

\section{Faktor Penyebab Disparitas Pembangunan Ekonomi Antar Kecamatan}

Faktor-faktor yang mempengaruhi disparitas ekonomi antar kecamatan di Kabupaten Cirebon diestimasi menggunakan metode data panel dengan pendekatan fixed effect dan random effect. Dasar statistika untuk memutuskan menggunakan pendekatan fixed effect atau random effect yaitu dengan $\mathrm{Uji}$ Hausman (Tabel 3).

\section{Tabel 3 Hasil Uji Hausman}

\begin{tabular}{|c|c|c|}
\hline Chi-Sq. Statistic & Chi-Sq. d.f. & Prob. \\
\hline 21,448190 & 3 & 0,0001 \\
\hline
\end{tabular}

Sumber: data diolah dengan Software Eviews 7

Nilai probabilitas Uji Hausman sebesar 0,0000, lebih kecil dari taraf nyata 5 persen. Artinya tolak $\mathrm{H}_{0}$, maka model yang digunakan adalah model fixed effect. Hasil estimasi model data panel menggunakan fixed effect model (Tabel 4). 
Tabel 4 Estimasi model data panel dengan menggunakan fixed effect

\begin{tabular}{ccccc}
\hline Variable & Coefficient & Std. Error & $t$-Statistic & Prob. \\
\hline C & -56.09166 & 26.28876 & -2.133675 & 0.0344 \\
LPE & -0.021910 & 0.088388 & -0.247882 & 0.8045 \\
LNPDRBK & -0.851067 & 0.313901 & -2.711265 & 0.0074 \\
LNTPK & -26.30930 & 12.30617 & -2.137895 & 0.0341 \\
\hline R-squared & 0.824568 & & & \\
F-statistic & 17.56986 & & & \\
Prob(F-statistic) & 0.000000 & & & \\
\hline
\end{tabular}

Sumber: data diolah dengan Software Eviews 7

Berdasarkan Tabel 3 dapat dilihat bahwa uji $\mathrm{F}$ menunjukkan angka signifikan dengan probabilitas $(F$ statistic $)=0,00000<\alpha(0,05)$. Artinya, secara bersama-sama pertumbuhan dari masing-masing variabel independen dalam model secara signifikan mempengaruhi pertumbuhan variabel dependen. Nilai $R$-squared sebesar 0,8246 artinya model secara representatif dapat menjelaskan keragaman variabel dependen sebesar 82,46 persen. Dalam metode estimasi panel data sering mengandung masalah heteroskedastisitas, tetapi dalam estimasi tidak mengandung masalah tersebut. Karena model ini diestimasi menggunakan Metode GLS White Heteroskedasticity-Consistent Standard Error and Covariance, sehingga diasumsikan model sudah bersifat homoskedastisitas.

Hasil analisis regresi panel menunjukkan, bahwa pendapatan (PDRB) per kapita berpengaruh negatif dan signifikan terhadap disparitas ekonomi. Artinya, setiap 1 persen peningkatan pendapatan (PDRB) per kapita maka akan menurunkan disparitas ekonomi antar kecamatan sebesar 0,851067 persen (ceteris paribus). Peningkatan pendapatan per kapita merupakan indikasi pendikatan pendapatan masyarakat yang akan berdampak terhadap peningkatan daya beli masyarakat, sehingga akan memperluas pasar untuk berbagai jenis barang dan jasa. Kondisi ini akan 74 mendorong peningkatan kegiatan investasi dan memperluas pembentukan modal, yang pada akhirnya akan dapat meningkatkan produktivitas dan perkembangan wilayah, serta terciptanya berbagai alternatif aktivitas ekonomi melalui pemanfaatan potensi lokal yang optimal. Dengan demikian peningkatan pendapatan (PDRB) per kapita dapat menurunkan disparitas ekonomi antar kecamatan yang ada di Kabupaten Cirebon.

Variabel tingkat perkembangan sektor ekonomi kecamatan juga berpengaruh negatif dan signifikan terhadap variabel disparitas ekonomi. Artinya, bahwa setiap 1 persen peningkatan perkembangan sektor ekonomi kecamatan maka akan menurunkan disparitas ekonomi antar kecamatan sebesar 26,31 persen (ceteris paribus). Berdasarkan hasil tersebut, penurunan disparitas ekonomi antar kecamatan dapat diselesaikan salah satunya melalui pengembangan sektor ekonomi yang mempunyai potensi daya saing kompetitif maupun komparatif yang lebih unggul dibandingkan dengan pertumbuhan total kegiatan ekonomi (Titisari 2010).

Dengan mengetahui beberapa faktor yang berpengaruh terhadap tingkat disparitas ekonomi antar kecamatan di Kabupaten Cirebon, maka pemerintah harus berupaya untuk menekan tingkat disparitas antar kecamatan tersebut dengan memaksimalkan pemanfaatan potensi lokal khususnya di kecamatan yang masih tertinggal. Salah satu cara untuk menurunkan tingkat disparitas antar kecamatan di Kabupaten Cirebon 
dapat dilakukan melalui pengembangan pusat pertumbuhan secara tersebar. Menurut Sjafrizal (2014), pengembangan pusat pertumbuhan (growth poles) secara tersebar dapat mengurangi disparitas pembangunan antar wilayah karena pusat pertumbuhan menganut konsep konsentrasi dan desentralisasi. Dengan penentuan pusat pertumbuhan, yakni wilayah dengan potensi paling kuat, diharapkan akan terjadi perembetan pertumbuhan bagi daerah-daerah di sekitarnya serta terjadi percepatan dan pemerataan hasil-hasil pembangunan (Restiatun, 2009).

Dari hasil beberapa analisis, maka pemerintah mempunyai tanggung jawab penting dalam mewujudkan pemerataan dan distribusi hasil-hasil pembangunan ke arah keseimbangan proporsional sesuai dengan potensi dan karakteristik masing-masing kecamatan. Setiap kecamatan diharapkan dapat mencapai tingkat pembangunan ekonomi, baik secara makro, meso dan mikro. Pada tingkat mikro bertujuan untuk mengenali kebutuhan yang mendesak dan memenuhi kebutuhan dasar masyarakat, membantu daerah dalam rangka mencapai kemandirian ekonomi dan meningkatkan daya saing, serta mendorong pengembangan potensi daerah agar mampu mengekspor hasil industri atau pertaniannya (Soedjito, 1997). Pada tingkat meso dilakukan pengembangan kecamatan dengan jalan mengaitkan antar kecamatan agar tercipta pusat-pusat pertumbuhan, yang seyogyanya diarahkan untuk mencapai hal-hal sebagai berikut:

1. Memperjelas hierarki kecamatan dengan menghindari dominasi kecamatan inti terhadap keamatan belakangnya sehingga timbul keserasian pembangunan dan arus urbanisasi dapat dikurangi.

2. Kecamatan yang telah memiliki sarana dan prasarana lebih lengkap diharapkan dapat lebih menyebarkan hasil-hasil pembangunan agar tidak terjadi pengurasan sumber daya dan eksploitasi kecamatan-kecamatan di sekitarnya.

3. Alokasi dana pembangunan lebih diarahkan untuk pembangunan investasi yang mendorong perkembangan ekonomi jangka panjang, terutama pembangunan infrastruktur.

\section{Prioritas Strategi Alokasi Anggaran untuk Penurunan Disparitas}

Prioritas pembangunan ekonomi di Kabupaten Cirebon menurut persepsi stakeholder dapat dilihat pada Gambar 6. Faktor utama yang berpengaruh terhadap disparitas pembangunan ekonomi antar kecamatan di Kabupaten Cirebon adalah pendapatan (PDRB) per kapita dengan nilai 0,494. Hal ini dapat terjadi karena peningkatan pendapatan per kapita sebagai indikasi meningkatnya pendapatan masyarakat dalam suatu kecamatan akan berdampak terhadap peningkatan daya beli masyarakat, sehingga akan memperluas pasar untuk berbagai jenis barang dan jasa. Kondisi ini akan mendorong peningkatan kegiatan investasi yang akan memperluas pembentukan modal. Modal yang makin meningkat akan dapat meningkatkan produktivitas dan perkembangan kecamatan melalui terciptanya berbagai alternatif aktivitas ekonomi karena adanya pemanfaatan potensi lokal yang optimal.

Aktor yang berperan dalam peningkatan pendapatan (PDRB) per kapita adalah masyarakat, dengan nilai 0,517. Hal ini menunjukkan bahwa partisipasi masyarakat sangat penting dalam proses pembangunan ekonomi. Sebagaimana menurut Arsyad (2016), bahwa pembangunan ekonomi daerah adalah suatu proses dimana pemerintah daerah dan masyarakatnya mengelola sumberdaya-sumberdaya yang ada dan 
membentuk suatu pola kemitraan antara pemerintah daerah dengan sektor swasta untuk menciptakan suatu lapangan kerja baru dan merangsang perkembangan kegiatan ekonomi (pertumbuhan ekonomi) dalam wilayah tersebut. Untuk mencapai tujuan tersebut, maka inisiatif dan partisipasi masyarakat sangat diperlukan perananya dalam pembangunan ekonomi.

Kendala utama untuk mengurangi disparitas pembangunan adalah aspek fisik dengan nilai 0,727 . Hal ini karena untuk membangun sarana dan prasarana fisik membutuhkan biaya yang sangat tinggi, apalagi jumlah kecamatan di Kabupaten Cirebon banyak yaitu 40 kecamatan, tentunya akan membutuhkan biaya sangat banyak untuk dapat memenuhi kebutuhan sarana dan prasarana fisik yang memadai terhadap semua kecamatan.

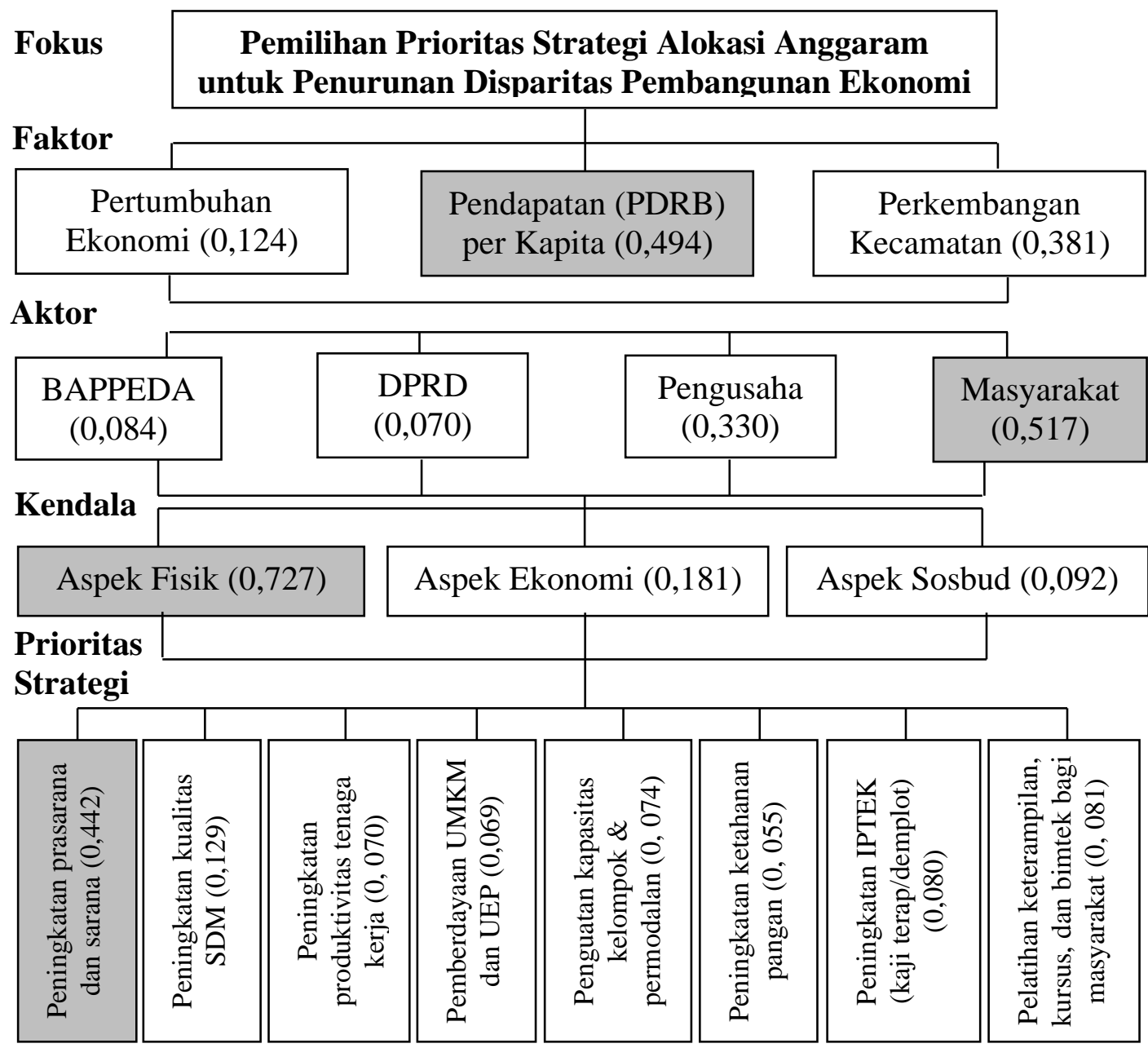

Gambar 6 Struktur dan nilai bobot hirarki strategi alokasi anggaran untuk penurunan disparitas pembangunan ekonomi di Kabupaten Cirebon 


\begin{tabular}{|l|l|l|}
\hline \hline Peningkatan prasarama dan sarana &, 442 \\
\hline Peningkatan kualitas SDM &, 129 \\
\hline Pelatihan keteramplan, kursus, dan bimtek bagi masyar: ,081 \\
\hline Peningkatan IPTEK (kaji terap/demplot) &, 080 \\
\hline Penguatan kapasitas kelompok dan permodalan &, 074 \\
\hline Peningkatan prodlutivitas tenaga kerja &, 070 \\
\hline Pemberdayaan UMKM dan UEP &, 069 \\
\hline Peningkatan ketalanan pangan &, 055 \\
\hline
\end{tabular}

\section{Gambar 7 Hasil sintesis menggunakan Software Expert Choice 11}

Berdasarkan Gambar 7, prioritas utama strategi alokasi anggaran untuk penurunan disparitas pembangunan ekonomi antar kecamatan di Kabupaten Cirebon adalah dengan peningkatan prasarana dan sarana antar kecamatan yang merata, hal ini sejalan dengan faktor utama yang mempengaruhi disparitas pembangunan ekonomi antar kecamatan di Kabupaten Cirebon, yaitu pendapatan (PDRB) per kapita. Peningkatan prasarana dan sarana dimaksud khususnya terkait mobilitas sumber daya antar kecamatan agar perekonomian dapat beroperasi secara optimal.

Dari hasil analisis di atas, maka sebaiknya Pemerintah Kabupaten Cirebon memprioritaskan peningkatan prasarana dan sarana, khususnya pembangunan jaringan transportasi antar kecamatan guna mendorong kelancaran mobilitas barang dan faktor produksi. Mobilitas barang dan jasa ini meliputi kegiatan perdagangan antar kecamatan dan migrasi spontan. Hal ini karena apabila mobilitas tersebut kurang lancar, maka kelebihan produksi suatu kecamatan tidak dapat dijual ke kecamatan lain yang membutuhkan. Demikian juga halnya dengan migrasi yang kurang lancar menyebabkan kelebihan tenaga kerja suatu kecamatan tidak akan dimanfaatkan oleh kecamatan lain yang sangat membutuhkannya. Sedangkan hasil analisis berdasarkan manfaat terhadap biaya, strategi alokasi anggaran yang diprioritaskan adalah peningkatan kualitas SDM. Strtategi ini dapat diambil apabila anggaran biaya terbatas.

\section{SIMPULAN}

Berdasarkan hasil dan pembahasan yang telah disajikan sebelumnya, dapat disimpulkan beberapa hal sebagai berikut:

1. Pola pertumbuhan ekonomi dan perkembangan wilayah tiap kecamatan di Kabupaten Cirebon, sebagai berikut:

a. Pendapatan per kapita kecamatan di bawah rata-rata sebanyak 25 kecamatan (62,50 persen), dan laju pertumbuhan ekonomi kecamatan di bawah rata-rata sebanyak 21 kecamatan $(52,50$ persen). Sedangkan pendapatan per kapita kecamatan di atas ratarata sebanyak 15 kecamatan (37,50 persen) dan laju pertumbuhan ekonomi kecamatan di atas rata-rata sebanyak 19 kecamatan (47,50 persen).

b. Analisis Tipologi Klassen menunjukkan bahwa kecamatan yang masuk kategori kuadran IV (relatif tertinggal) sebanyak 18 kecamatan (42,50 persen), kuadran I (maju dan tumbuh cepat) sebanyak 11 kecamatan (27,50 persen), kuadran III sebanyak 8 kecamatan $(20,00$ persen), dan kuadran II sebanyak 4 kecamatan (10,00 persen). Analisis Indeks Entropi diketahui bahwa kecamatan dengan nilai entropi tertinggi dan sekaligus 
sebagai kecamatan dengan tingkat perkembangan tinggi sebanyak 2 kecamatan (5,00 persen), yaitu Kecamatan Palimanan dengan nilai entropi 0,309 dan Kecamatan Plumbon dengan nilai entropi 0,272. Sedangkan kecamatan dengan tingkat perkembangan sedang sebanyak 16 kecamatan (40 persen), dan kecamatan dengan tingkat perkembangan rendah sebanyak 22 kecamatan (55 persen).

2. Sumber utama penyebab disparitas berasal dari disparitas antar kecamatan dalam wilayah (within region), dan dari tahun ke tahun cenderung mengalami peningkatan, yaitu sebesar 81.68 persen pada tahun 2010 meningkat menjadi 83,98 persen pada tahun 2015. Sedangkan disparitas antar wilayah (between region) antara WBB dan WBT di Kabupaten Cirebon cenderung mengalami penuruna, yaitu sebesar 18,32 persen pada tahun 2010 menurun menjadi 16,02 persen pada tahun 2015.

3. Faktor yang signifikan berpengaruh terhadap penurunan disparitas pembangunan ekonomi antar kecamatan di Kabupaten Cirebon adalah pendapatan (PDRB) per kapita dan perkembangan kecamatan, sedangkan pertumbuhan ekonomi secara statistik tidak signifikan.

4. Persepsi steakholder di Kabupaten Cirebon menempatkan faktor pendapatan (PDRB) per kapita sebagai prioritas utama dalam kegiatan pembangunan ekonomi. Aktor atau pelaku utama dalam pembangunan ekonomi adalah masyarakat. Kendala utama dalam pemerataan pembangunan ekonomi aspek fisik. Prioritas utama strategi alokasi anggaran untuk penurunan disparitas pembangunan ekonomi di Kabupaten Cirebon adalah peningkatan prasarana dan sarana antar kecamatan.

\section{DAFTAR PUSTAKA}

Amrillah dan Yasa IN. 2013. Analisis Disparitas Pendapatan Per Kapita Antar Kecamatan dan Potensi Pertumbuhan Ekonomi Kecamatan di Kabupaten Karang Asem [jurnal]. E-Jurnal Ekonomi Pembangunan Universitas Udayana, Volume 2, Nomor 4: 181-189.

Arsyad L. 2016. Pengantar Perencanaan Pembangunan Ekonomi Daerah. Edisi Ketiga. Yogyakarta(ID): BPFE-Yogyakarta.

Badan Pusat Statistik Provonsi Jawa Barat. 2016. Provinsi Jawa Barat dalam Angka 2016. Bandung (ID): BPS Provinsi Jawa Barat.

Badan Perencanaan Pembangunan Daerah Kabupaten Cirebon. 2016. Produk Domestik Regional Bruto (PDRB) Menurut Lapangan Usaha Per Kecamatan Kabupaten Cirebon Tahun 2011-2015. Cirebon (ID): Bappeda Kabupaten Cirebon.

Falatehan AF. 2016. Analytical Hierarchy Process: Teknik Pengambilan Keputusan untuk Pembangunan Daerah. Yogyakarta (ID): Indomedia Pustaka.

Gujarati DN. 2010. Dasar-dasar Ekonometrika. Jakarta (ID): Erlangga.

Kuncoro M. 2002. Analisis Spasial dan Regional: Studi Aglomerasi dan Kluster Industri Indonesia. Yogyakarta (ID): UPP AMP YKPN.

Muhlighaus, Sabine \& Walty, Samuel. 2001. Endogenous Development in Swiss Mountain Communities [journal]. Montain Research and Development, Volume 21, No. 3: 236-242. 
Restiatun. 2009. Identifikasi Sektor Unggulan dan Ketimpangan Antar Kabupaten/Kota di Provinsi Daerah Istimewa Yogyakarta [jurnal]. Jurnal Ekonomi dan Studi Pembangunan, Volume 10, Nomor 1:77-98.

Sjafrizal. 2014. Ekonomi Wilayah dan Perkotaan. Jakarta (ID): PT. Rajagrafindo Persada.

Soedjito BB. 1997. Strategi Pengembangan Kawasan Timur Indonesia dalam Bunga Rampai Perencanaan Pembangunan di
Indonesia. Jakarta (ID): PT. Gramedia Widiasarana Indonesia. Titisari KH. 2010. Identifikasi Potensi Ekonomi Daerah Boyolali, Karanganyar, dan Sragen [jurnal]. Jurnal Ilmiah Orasi Bisnis, Edisi IV, 9-27.

Todaro MP dan Smith SC. 2011. Pembangunan Ekonomi Edisi kesembilan Jilid 1. Devri Barnadi,dkk (Ed). Jakarta (ID): Penerbit Erlangga. 